\title{
Being a good spy: legitimising access to web-based observation
}

\author{
Ingeborg Mikalsen Gronning
}

Department of Sociology and Political Science, Norwegian University of Science and Technology, ingeborg.gronning@gmail.com

DOI: http://dx.doi.org/10.5324/eip.v9i2.1864

(cc) BY

This is an open access article distributed under the terms of the Creative Commons Attribution 4.0 International License, which permits unrestricted use, distribution, and reproduction in any medium, provided the original author and source are credited.

Observation of online forums is a relevant methodological approach for researchers in several disciplines. However, ethical guidelines on such observations challenge the ethically concerned researcher. In this paper, I reflect on how I carried out my observation of an online weight-loss forum, and how I could have conducted it differently to meet ethical standards and the demands of high-quality research. After receiving approval from the forum administrators to observe the forum, information about my project on obesity was posted online. Some of the participants reacted negatively to my presence in the forum. This paper draws on the evolving discussion between researcher and participants on the complex issue of research ethics, particularly informed consent, in studying closed forums on the Internet. It is suggested that evaluating whether participants are harmed is more important than the public/private divide when considering whether informed consent is necessary.

Keywords: Internet-based research, research ethics, informed consent

\section{Introduction}

Through the Internet, web-based communities can appear and exist beyond the limits of time and space (Szmigin \& Reppel 2004). The Internet represents a relatively new space for online interaction, where communities are created on the basis of shared interests, common challenges or health issues. Researchers can access data easily through the Internet without spending lots of time recruiting participants. Data can be generated online directly through research queries or indirectly by gathering posts from chat rooms and newsgroups (Mann 2003: 34). Huge amounts of data are easily accessible, but ethical guidelines differ on three main issues: (1) online spaces as public or private, (2) obtaining informed consent from participants, and (3) assuring anonymity in published research (Knobel 2003: 190). Because of the blurred line between the public and private areas of cyberspace, the guidelines often call on researchers to weigh the benefits and drawbacks when 
deciding whether informed consent is necessary (Association of Internet Researchers 2012). People in public places can be observed without their consent, whereas observations of people in private places require participants' consent (Norwegian National Committee for Research Ethics in the Social Sciences and the Humanities 2012). Researchers have to consider this blurred line when conducting research online, and must try to ensure anonymity for participants. Anonymity in studies of online communities raises difficult ethical challenges. The IP address can be used as identifying information, as many online participants use the same pseudonym in several online environments (Bruckman 2002). Some also add private photos to their profiles, which may reveal their identity.

People with stigmatising illnesses are more likely to use the Internet than others (Berger, Wagner \& Baker 2005), which makes the Internet a useful arena for research on stigmatised groups. People who are obese often experience stigma (Grønning, Scambler \& Tjora 2013). Interviews with obese participants have indicated that online forums for weight loss have great importance for this group. With this in mind, I observed an online weight-loss forum, which later resulted in a paper on online interaction (Grønning \& Tjora 2015). While observing the forum, I realised that obtaining participants' approval to use quotes is not easy. My experience from earlier studies (Tjora, Henriksen, Fjærli \& Grønning 2012; Grønning, Scambler \& Tjora 2013; Grønning 2014) is that people are generally positive towards participation in research projects in real-time, physical space. In these projects, the participants consider that contributing to research is important and the chance of being harmed or having their identity revealed is minimal. However, researchers who observe people on the Internet face other challenges.

Although researchers have an ethical responsibility when doing research, they also have a responsibility to produce research of high quality. While doing my research, I found it difficult to meet the gold standard of research ethics while obtaining high-quality data. In my observations of the interactions in the online weight-loss forum, I found that telling the members of the forum about my presence probably caused more harm than it would have done if I had omitted acknowledging my existence. Ethical guidelines carry messages, meanings and intentions from the organisation to the research field (Smith 2007). The discourse of research ethics weaves together the formal guidelines and the researcher's everyday practice, and the researcher's products are shaped in this interplay. This paper poses the following question: Can adhering to ethical guidelines harm participants more than a strong, but pragmatic, self-regulated ethical approach would?

In the present paper, I review current discussions about Internet ethics, with a special focus on the blurred line between public and private spheres. I also examine national ethical guidelines and recommendations for Internet research. I present the online weight-loss forum and illustrate my research approach, how the participants reacted to my presence and how I handled the demands of consent and anonymity. I refer to informed consent as a gift from the participants and discuss why acquiring informed consent from forum participants can be difficult. I suggest that a more pragmatic approach may be more ethical than an approach that requires informed consent. 


\section{Ethical guidelines for Internet research}

Ethical guidelines make sharp distinctions between observations of public and private spaces. Written text in forums and newsgroups is considered public and is often compared to information collected from television and other public records. On the other hand, observations of closed forums without consent are often considered unethical (Rodham \& Gavin 2006). However, the definitions of 'private' vary. According to Mann (2003), online forums should be treated as private when used as if they are private. Mann (2003: 37) defined 'private' as a place where individuals can reasonably expect that observations are not taking place. Expectations of privacy differ from one culture to another, which makes the level of privacy difficult to measure. Closed forums that require registration can have a private feel, although they are easily accessible. Established norms and codes, aims and target audience can also influence how private the forum feels (Eysenbach \& Till 2001). Moreover, people often post from their homes, which supports a false sense of privacy (King 1996). According to King, special care should be exercised when groups with a high perception of privacy are studied, as they may expect their readers to understand and support their situations.

Online spaces can also be seen as public. Cavanaugh (2000) considered all online spaces public, with reference to Goffman's $(1963 ; 1971)$ theories; it is accepted that lurkers 'listen in' on online conversations. When lurkers present themselves, they are usually welcomed to the community, which makes sense only if the Internet is seen as a public place. The reaction would be different if someone suddenly revealed his or her presence in another's telephone conversation. Online conversations are usually not in real time, which makes the comparison with telephone conversations more complicated than stated by Cavanaugh. However, this is still an interesting perspective.

\section{National research guidelines}

The guidelines for research ethics in Norway are administered by the Norwegian National Committee for Research Ethics in the Social Sciences and the Humanities (NESH 2012). The general ethical guidelines are covered in 47 paragraphs, while a separate document deals with the Internet as a research arena (NESH 2014). The guidelines state that informed consent is not mandatory in situations where the research does not involve physical contact with participants, where private life and close relationships are handled carefully, where the information is non-sensitive and where the value of the research has greater advantages than the drawbacks. It is made clear that observations can normally be done in public places, but if technical devices are used, the rule does not apply and informed consent is necessary. The guidelines for Internet research (NESH 2014) emphasise the challenge posed by the Internet as a space somewhere between public and private. Members of the same forum may have different ideas of the forum's privacy and their participation will depend on their understanding. NESH describes the divide as dependent on whether the information online has a private character and whether the space studied has restricted admission, as participants in restricted forums may presume that they are protected. The guidelines state that researchers cannot, without informed consent from participants, use information from forums that is not 
publicly available. Whenever the researcher is actively involved in the interaction, the researcher should make himself or herself known to the forum beforehand (NESH 2014). This should also be considered when the researcher is not actively involved. The guidelines emphasise that personal or sensitive information about people must, in all cases, be anonymised and treated and used in a proper way. The people involved have the right to decide whether or not information about them can be used for research. The possibility of tracking the participants by doing a text search of quotes should also be considered (NESH 2014).

Sociologists in the United Kingdom follow the guidelines for ethical research of the British Sociological Association (BSA 2002). The BSA guidelines contain only one paragraph about Internet research:

41) Members should take special care when carrying out research via the Internet. Ethical standards for Internet research are not well developed as yet. Eliciting informed consent, negotiating access agreements, assessing the boundaries between the public and the private, and ensuring the security of data transmissions are all problematic in Internet research. Members who carry out research online should ensure that they are familiar with ongoing debates on the ethics of Internet research, and might wish to consider erring on the side of caution in making judgments affecting the well being of online research participants (BSA 2002: 5-6).

The Association of Internet Researchers (AoIR 2012) has also developed recommendations for ethical decision-making and Internet research. They underline that the more vulnerable a community, the greater the researcher's responsibility to protect the community. The subjects' rights should be balanced with the social benefits of the research and the right to conduct research. Whereas a code of practice should be strictly followed, guidelines are more flexible. The AoIR provides a set of guidelines instead of a code of practice 'so that ethical research can remain flexible, be responsive to diverse contexts, and be adaptable to continually changing technologies' (2012: 5).

The common thread of the guidelines presented above is trust in the researcher's judgment of how to conduct ethically sound research. Being up to date on the current scientific discussion about ethical guidelines for Internet research is as important as following the ethical guidelines. In my observations of the forum, I did my best to practise good ethics, but ended up feeling like an intruder with access to lots of good data that I could not use. In the following sections, I present my approach to the forum.

\section{Observations of an online weight-loss forum}

Research projects that gather personal information in Norway are required to apply to the Norwegian Social Science Data Services (Norsk samfunnsvitenskapelig datatjeneste (NSD) 2014) for approval. I carried out observations of the online weight-loss forum in autumn 2011. As I was not intending to collect direct or indirect information about the participants, it was not necessary for me to get approval from the $\mathrm{NSD}^{1}$ (2014) before starting the observations. The forum had over 3,000 members, more than 8,000 different subjects and over 16,000 posts at the time of observation. The forum was divided into sections related to weight loss and 
contained personal diaries. Anyone who registers a user profile can obtain access to the forum. I therefore regard it as a space somewhere between private and public; private because participants have to log on, public because anyone can log on. Because of the log-on barrier, members are assured that quotes from the forum will not pop up in online searches.

My particular interests in observing the forum were what themes were discussed online and how the communication was framed. I wanted to comply with ethical standards, and aimed to do everything correctly. Having read guidelines and academic papers about Internet ethics, I understood that the forum occupied a space between private and public, and that its exact placement in that space depended on the participants' perception and use of it, which I could only find out through analysing it. I found that some of the participants used it for personal matters such as making private arrangements, which convinced me that it should be regarded as a private space.

The first step was to get permission from the forum administrators. Luckily, they responded positively. We agreed that I would post a thread online presenting the project. After several discussions with my supervisor and approval of the text from the administrators, I posted the following:

\section{Hi!}

I'm a PhD student in sociology working on a project about personal health records. My main focus is people that have gone through bariatric surgery or lifestyle change programmes. I am interested in finding out more about what tools patients find useful before and after treatment.

I have interviewed 22 people who have gone through treatment. Many of my informants find this forum helpful.

In the coming weeks I will observe the activity online. I hope to get a glimpse of how the forum can help people who are going through bariatric surgery.

Best regards, Ingeborg Grønning

When I logged on about an hour later, I had already received a few replies. ${ }^{2}$ These participants saw my observation as a form of trespassing. Their replies were negative: 'Has this been cleared with the administrators? I don't like being surveilled' (Amy). Surprised to receive these negative replies, I realised I should have added more information about the project. I edited my post accordingly and assured participants that I would not quote them directly.

I will observe the activity online for one week. I hope to get a glimpse of how the forum can help people who are going through bariatric surgery. I will not use quotes or other personal information in my project; I just want to get an overview of how the forum is used. The administrators have approved this beforehand.

After this edit, the responses were mainly positive. Within 30 hours, I had received about 20 replies. A sample of the replies follows. 
I think it's positive that someone wants to do research [on this theme]. She's said that she won't use quotes or do anything that will identify any of us. It's important to remember that this is an open forum that anyone can read and get what they want from. I think it's great that this person has permission from the administrators and is letting us know what she is doing. (Camilla)

I think this can be of great help for our descendants, not to mention ourselves, for better or worse ... As already mentioned, this is an open forum that anyone can 'monitor'. (Diana)

With permission from the administrators and as part of a project, I think this is great! There are already many people who just read and never register. It's great that she lets us know who she is. (Ella)

Ok. I'd appreciate it if you let us know when the research period is over. Edit: I can see that the first post is changed. When I read the first post it said that she would follow the forum for a period. (Amy)

The participants seemed to have a realistic image of the forum; many of them were aware that the forum was open to the public. After a rough start, I was happy to receive positive replies, and posted the following comment.

I'm glad you're positive towards me following the forum activity! It's great that you find support in the forum. It seems like a nice arena for sharing information, encouragement and support.

Comments from other participants also supported my research. Participant Jenny replied that she found research positive, and mentioned that research is about observing and not monitoring, which cannot be compared. A few of the posters were glad that I had informed the forum about my presence. Despite the additional information and the positivity of most participants, some remained sceptical.

It's good that [...] the administrators have approved it and that there's more information about the project and where it will be published. When I read the first post yesterday, there was very little information, which made it seem unserious, but now I think it's ok, even though I'm still a little sceptical of this kind of observation of Internet forums.

Reply to an earlier post: If you're a serious researcher, you can't observe people and use the observations without letting people know who you are. (Amy)

Although online lurkers are usually welcomed to the forum when they reveal their presence, I was not so welcomed at first. My aim was to analyse the forum for a scientific publication; my presence could not be compared with that of harmless lurkers. I was still going to follow ethical guidelines to ensure that no harm was being done to participants.

\section{Analysing the forum and changing the approach}


The forum's volume was overwhelming. After a few days of scrolling through diaries, pictures and stories about failure and success, I found one diary from a woman who seemed to be particularly active. She wrote a daily diary in the forum and actively commented on other people's posts. I interviewed the writer and did a structured analysis of this particular diary's posts and replies. The analysis of both interview and diary is presented in another paper (Grønning \& Tjora 2015). In the process, I realised that I had to break my promise to the participants, as observations had to be longer than one week and quotes were necessary to make an adequate analysis. With permission from the administrators, I dealt with these issues by gaining informed consent from the participants whose quotes I wanted to use. I therefore contacted the forum participants through a message function in the forum. Having failed to obtain all the consents, I had to leave them out of the analysis, which led to a less substantive presentation than anticipated. The quotes I finally used were translated into English, the participants were given new pseudonyms and the forum's name was never mentioned. It seemed as if I had restricted my data collection unnecessarily, and made a few participants anxious in the process. Nevertheless, my frustration with trying to do everything 'correctly' and having my aspirations somewhat curtailed gave me the idea for this article.

The administrators granted me permission to contact the participants who had commented on my post through a message function in the forum. I also posted a new comment telling the participants about my new project, mentioning that my observations had resulted in a paper about communication in the online weight-loss forum and setting out my thoughts and intentions:

Reacting with scepticism to these kinds of projects is natural, as many of you consider the forum a private arena. Methodologically, it is interesting that some react with scepticism. Researchers follow ethical guidelines. A researcher will never ${ }^{3}$ publish anything that reveals an informant's identity or puts the informant at any kind of risk. In my case, all quotes were translated to English, the forum's name was not mentioned and all nicknames were changed to pseudonyms. This makes it impossible ${ }^{4}$ to reveal the participants' identity, for example through a search on Google. There is no guarantee that other forum participants have honourable intentions with their participation; they can post quotes on Facebook, blogs or other forms of social media. The forum participants do not seem to worry about this. I, on the other hand, have encountered scepticism because my ethical responsibility requires me to be open about my activities and intentions.

I am contacting you because I want to write a methods paper about this. The paper's focus will be the researcher's encounter with reluctant informants and how researchers can handle this. A lot of research is done through different forms of Internet forums, and more knowledge about researchers and forum participants is of great value. My paper's aims are to discuss how to do research on these kinds of Internet forums and how to respect sceptical attitudes from participants but at the same time develop the trust you need to do ethical research in these contexts. 
The final part of the post explained that I wanted the discussion to be as accurate as possible, which was why I wanted to use my post and the replies I received as a starting point for the paper.

My first post with its associated thread had been viewed about 450 times. I did not know who these viewers were, or how many of them approved or disapproved of my observation. I received replies from seventeen participants, and of these about half gave me their informed consent. Some never opened my message, and a few did not respond, demonstrating their choice not to participate. Since the individual level of participation in online forums varies, this response rate did not come as a surprise. In the next sections, I discuss why obtaining consent from participants online is complicated, and I suggest that research without informed consent may sometimes be a less harmful procedure.

\section{Discussion}

For a researcher, reading and applying ethical guidelines is about doing ethically correct research. A written set of guidelines standardises the researcher's ethical procedures, but the flexibility of the ethical guidelines requires that the researcher evaluate how they should be implemented. Internet research is complicated terrain. In my own online research, excess caution on my part harmed some of the forum participants by making them anxious; as a result, some of the data were lost. My first post was met with negative reactions from a few participants; the second, with positive feedback. I might have received more negative replies if I had not added the extra information. Similarly, I might also have avoided negative replies if my first post had included my institutional affiliation, if I had assured the participants that I would not generate or pass on personal information and if I had told them more openly about the purpose of my observation. I was new to Internet research at that point and did not realise how the forum participants would react. Nevertheless, most participants commented that the forum is an arena that is open to the public, that anyone can access and 'get what they want' from the forum and that research can actually be of help for their group. Despite the addition of new information and the fact that other participants had expressed their support, a few participants remained sceptical. This balance of outcomes is almost inevitable in research. The following example, from King (1996: 122), illustrates how one of the members reacted when he realised that the forum he participated in was the subject of research: 'I certainly don't feel at this point that it is a "safe" environment, as a support group is supposed to be, and I will not open myself up to be dissected by students or scientists.'

With a few exceptions (Cavanaugh 2000; Pothier 2008), there seems to be general agreement among researchers and ethical committees that open forums may be regarded as public spaces, while closed forums should be treated as private (BSA 2014; NESH 2012; Rodham \& Gavin 2006). Unfortunately, the feeling of privacy does not always coincide with the technical privacy of the forum. In a study of participant objections to being studied and the ethics of chat room research, Hudson and Bruckman (2004: 134) analysed how people react to participating in online studies. A total of 525 chat rooms were included in the study. Hudson and Bruckman (2004: 134) found that operators 'kicked them out' from two thirds of the chat rooms where they attempted to obtain informed consent, with additional 
comments such as, 'This is a private room, no studies needed' or 'I SAID SHOO'. The Georgia Tech Institutional Review Board gave Hudson and Bruckman permission to do the study without obtaining informed consent, as long as they excluded all sensitive forums from the study and minimised the risk of harm.

As already mentioned, the information I collected did not contain any personal information. Thus, there was no need to apply for permission from the NSD (Norsk samfunnsvitenskapelig datatjeneste 2014) to conduct the research without consent. Since obese people may experience stigma based on their appearance (Grønning, Scambler \& Tjora 2013), and the forum was a site where they discussed body-related topics, I considered the forum sensitive. When dealing with sensitive participants and themes, research may potentially pose a threat (Dahl 2012; Renzetti \& Lee 1993). The participants believe that their readership understands and supports their comments, which, according to King (1996), calls for special care. The forum had a supportive culture, in which negative posts were replied to with sympathetic comments. It could be defined as public because of its accessibility, but given the matters discussed online and the sensitivity of the group, I considered it private. Therefore, I decided to tread carefully, presented myself online and asked participants for consent to quote them.

\section{Informed consent from online participants}

Asking a whole group for permission is usually not a good way to go about obtaining informed consent, as it can have negative effects on forum interaction (King, 1996). Moreover, memberships change frequently, and asking all members for permission is no guarantee that everyone will feel they have given their consent. However, having consulted the forum administrators, I decided to write a post about the project.

Obtaining online informed consent in particular can be a problem, since people can pass themselves off as someone else. It was not an option to meet the participants face to face because they were located all over the country. I decided that electronic confirmation would be sufficient. Several of the participants who gave their consent added their telephone number so that I could reach them if necessary. As already mentioned, I did not obtain informed consent to use all the quotes I wanted to use in the article, and had to erase some material that had already become part of the initial analysis. When people choose not to participate in interviews, the researcher does not 'lose' data in the same way. Even though I was aware of this early on, it was still frustrating to miss data like this.

I had no means to encourage participation and was dependent on the participants' willingness to contribute to my research project. Mauss's (1990) concept of the gift can be useful for understanding why people choose to participate or not to participate in research projects. History is filled with examples of how gifts lead to reciprocal exchange. According to Mauss (1990), a gift is never just a gift, but an act that creates binding relations. When someone receives a gift, there is an implied understanding that the receiver will give a gift in return. Within Norwegian social science, researchers usually do not offer people gifts for participation, hoping instead that people will take part for other reasons. In biobank projects, people may donate samples and data because they benefit personally by receiving reassurance about their health or the progress of their condition, or because they want to help 
other people and medical science (Healthtalkonline 2014b). Donating samples and data is a type of gift, and the exchanged gift is a contribution to public knowledge or the personal benefit of a health check. Diana was one of the forum participants who gave me permission to use her quote, in which she stated that the research could be helpful for the forum members, including herself. It is unlikely that the study of the communication in the online forum will help these participants directly, but my aim is that my research can lead to a better understanding of this group's challenges. The quote is Diana's gift, and my research, which may possibly help her group of patients, is the reciprocated gift.

However, not all the participants had the same attitude. Although their participation entailed giving me their informed consent without any further involvement, this consent was difficult to obtain, unlike my experience with consent to perform in-depth interviews. There are important differences between an indepth interview and quotes from web forums. During an interview, the informant talks to an interested listener, and the feeling of contributing to research can be gift enough. The interviewee can choose what to say; in contrast, there is no way to change a quote posted on the Internet. People in public areas can be observed without informed consent, and researchers often observe where and how people move. On the Internet, observations are based on written text, which allows the writer to be more easily identified. This makes the observations more ethically complicated. I did everything I could to minimise harm: the forum's name was not mentioned, participants were given pseudonyms and quotes were translated. Nevertheless, it is understandable that some individuals chose not to participate. Participants were contacted via a message function in the forum; they had no opportunity to meet the researcher and felt no obligation to participate. Saying 'no' or simply not responding to the request was easy.

In both my first and subsequently edited posts to the forum, I wrote little about the project and myself, naïvely thinking that the information I provided was sufficient. In retrospect, I realise that I should have written more about myself and who was financing the project. I should have assured the participants of their anonymity, which I later did in the edited text, and also made clear that the administrators had approved the project. Despite these assurances, a few participants remained sceptical.

\section{Observation without informed consent}

In a social science research context, harm is usually associated with revealing the participants' identity. Mill (1998) claimed that participants who are unaware that their messages are being analysed cannot be harmed. On the other hand, King (1996) believed that there is a chance of harming participants in situations where they are unaware that their messages are being analysed until the results of the study are published. Although researchers do what they can to minimise harm, participants may feel they have been wronged if they discover that they have been the subjects of research without their consent. I still think it is permissible to 'wrong' people if the wrong that is committed is minor when compared to the importance of the research. Hudson and Bruckman (2005) carried out their study without obtaining consent from participants, doing what they could to reduce potential harm. They left out groups that were sensitive and considered the scientific value of 
their possible findings greater than the drawbacks associated with conducting the process.

In my view, this study would best be conducted without consent from participants, because it would harm the participants less than obtaining their consent. I did what I could to anonymise the participants and I felt as if I was doing more harm through upsetting and worrying them. Pothier (2008) also claimed that written consent may sometimes cause more anxiety than protection. He suggested that 'ethics committees should actually consider requesting the removal of written consent as a requirement' (Pothier 2008: 78). There is no easy way of addressing this issue, but if material is published without consent, it must be anonymised to such a degree that the participant can be confident that he or she is the only person who will recognise the material.

Ethical guidelines affirm that public spaces can be observed without consent from participants, whereas private spaces can be observed only with participants' informed consent. Online, there is no sharp distinction between public and private. The public-private dichotomy can be seen in light of Goffman's (1969) dramaturgical metaphor, where the front stage is related to behaviour in public, while private matters are done back stage. Goffman's metaphor breaks down in relation to mediated communication. The forum is a 'communication community' (Delanty 2003), where forum interaction is a digital front stage. While some individuals use their full names, others choose nicknames and limit their profile information so as to be unrecognisable and to reveal their identity only when they want to. Participants who read and comment without leaving identifiable traces maintain their privacy, and the back stage is hidden behind the computer screen. Rettie (2009: 427) described this as one area being the 'front region of one performance and the back region of another'. Tjora's (2011) term 'communicative transparency layer' is pertinent to our discussion of participation in online forums. Online forums can be observed anonymously, or participants can jump in and interact with others. Participants who observe without informing the forum about their presence remain back stage until they interact in that particular communicative transparency layer and participate on the front stage. How participants interact within the forum's communicative transparency layer illustrates that the public/private divide is irrelevant online. Whether participants are harmed is a better measure of how a forum should be treated. My silent observation does not affect anyone while it is going on, although harm may arise if participants recognise their quotes in my publication. If participants do recognise their words, they should feel secure in the protection of their anonymity and hopefully appreciate the importance of the research. I have no clear solution to this paradox, but I believe that it is important to continue this discussion. A growing proportion of social interaction happens online, and many researchers are interested in accessing this material, but the difficulty regarding online informed consent makes it easier to do research on phenomena that happen offline. In contrast, journalists have virtually free access to whatever they find online.

\section{Conclusion}

Ethics in relation to research methodology is part of a researcher's training, and researchers are expected to be capable of protecting participants, keeping them out 
of harm's way and anonymising their data. Conducting ethical research does not just mean informing the participants and obtaining informed consent; it may also mean protecting participants from the insecurity and worry that result from a sudden request for informed consent to use data from a web-based forum. Less harm could be done if researchers were free to evaluate which ethical approach would best protect the participants. Whether such a generic authorisation of the researcher's self-managed ethics (which exists in a variety of professions) is feasible is also a political question. Addressing this question more openly, however, could help to further develop social research that is based on obtaining and applying empirical data from the Internet.

\section{Acknowledgements}

Thanks to the administrators and participants of the forum. For helpful comments on earlier versions of this article, I thank my adviser, Professor Aksel Tjora, and Graham Scambler and Ingvill Stuvøy. Thanks also to the editors at the Nordic Journal of Applied Ethics and to the anonymous reviewer for insightful comments.

\section{Notes}

${ }^{1}$ NSD is a research ethics commitee.

${ }^{2}$ The author has been given permission to use the quotes reproduced here. All names are pseudonyms.

${ }^{3}$ There are few things that 'never' happen. In retrospect, this was not the best choice of word.

${ }^{4}$ The word 'impossible' should also have been qualified.

\section{References}

Association of Internet Researchers (2012). Ethical decision-making and Internet research. Recommendations from the AoIR Ethics Working Committee [Online]. Available at: http://aoir.org/reports/ethics2.pdf [Accessed 2 August 2014].

Berger, M., Wagner, T.H. and Baker, B.C. (2005) Internet use and stigmatized illness. Social Science and Medicine, 61: 1821-1827. http://dx.doi.org/10.1016 /j.socscimed.2005.03.025

British Sociological Association (2002). Statement of ethical practice for the British Sociological Association (2014/03/14). http://www.britsoc.co.uk/media/27107 /StatementofEthicalPractice.pdf?1411652634286

Bruckman, A. (2002). Studying the amateur artist: a perspective on disguising data collected in human subjects research on the Internet. Ethics and Information Technology, 4: 217-231. http://dx.doi.org/10.1023/A:1021316409277

Cavanaugh, A. (2000). Behaviour in public? Ethics in online ethnography. Cybersociology Magazine, 6 (2014/08/20). http://www.cybersociology.com/files /6_2_ethicsinonlineethnog.html 
Dahl, S.L. (2012). Sensitive tema og hårsåre informanter som metodologiske utfordringer i kvalitativ forsking. Sosiologisk tidsskrift, 20: 7-26.

Delanty, G. (2003). Community. London: Routledge.

Eysenbach, G. and Till, J.E. (2001). Ethical issues in qualitative research on Internet communities. British Medical Journal, 323: 1103-1105. http://dx.doi.org /10.1136/bmj.323.7321.1103

Goffman, E. (1963). Behaviour in public places: notes on the social organization of gatherings. New York: Free Press/Macmillan.

Goffman, E. (1969). The Presentation of Self in Everyday Life. Harmondsworth: Penguin.

Goffman, E. (1971). Relations in Public: Microstudies of the Public Order. Harmondsworth: Penguin.

Grønning, I., Scambler, G. \& Tjora, A. (2013). From fatness to badness: the modern morality of obesity. Health, 17: 3: 266-283. http://dx.doi.org/10.1177 /1363459312447254

Grønning, I. (2014). Fedmefortellinger: Om vektnedgang og biografiske opprykk. Sosiologisk tidsskrift, 3: 227-247.

Grønning, I. and Tjora, A. (2015). Digital absolution: Confessional interaction in an online weight-loss forum. Manuscript submitted for publication.

Healthtalkonline (2014a). Biobanking. Reasons for wanting to take part - personal benefit (2014/06/11). http://www.healthtalk.org/peoples-experiences/medicalresearch/biobanking/reasons-wanting-take-part-personal-benefit

Healthtalkonline (2014b). Biobanking. Reasons for wanting to take part - helping medical science and other people (2014/06/11). http://www.healthtalk.org /peoples-experiences/medical-research/biobanking/reasons-wanting-takepart-helping-medical-science-other-people

Hudson, J.M. and Bruckman, A. (2004). 'Go away': participant objections to being studied and the ethics of chatroom research. The Information Society, 20: 127139. http://dx.doi.org/10.1080/01972240490423030

Hudson, J.M. and Bruckman, A. (2005). Using empirical data to reason about Internet research ethics. In: Ninth European Conference on ComputerSupported Cooperative Work: 287-305, 18-22 September 2005, Paris. http://dx.doi.org/10.1007/1-4020-4023-7_15

King, S.A. (1996). Researching Internet communities: proposed ethical guidelines for the reporting of results. The Information Society, 12: 119-127. http://dx.doi.org /10.1080/713856145

Knobel, M. (2003). Rants, ratings and representation: ethical issues in researching online social practices. Education, Communication and Information, 3: 187210. http://dx.doi.org/10.1080/14636310303141

Mann, C. (2003). Generating data online: ethical concerns and challenges for the C21 researcher. In: Thorseth, M. (ed.) Applied ethics in internet research (3149). Trondheim: Norwegian University of Science and Technology. 
Mauss, M. (1990). The gift: the form and reason for exchange in archaic societies. London: Routledge.

Mill, J.S. (1998). Utilitarianism. In: Crisp, R. (ed.) J.S. Mill: Utilitarianism. New York: Oxford University Press (47-107).

Norsk samfunnsvitenskapelig datatjeneste (2014). Skal det registrers personopplysninger? (2015/01/15). http://www.nsd.uib.no/personvern /meldeplikt/meldeplikttest

Norwegian National Committee for Research Ethics in the Social Sciences and Humanities (2012). De forskningsetiske retningslinjene og loven [Ethical guidelines for research and the law] (2014/03/11). https://www.etikkom.no /Forskningsetikk/Etiske-retningslinjer/Samfunnsvitenskap-jus-og-humaniora /A-Forskningsetikk-forskningsfrihet-og-samfunn-1---4/

Norwegian National Committee for Research Ethics in the Social Sciences and Humanities (2014). Etiske retningslinjer for forskning på internett [Ethical guidelines for research on the Internet] (2015/05/12). https://www.etikkom.no /globalassets/documents/publikasjoner-som-pdf/forskningsetiskeretningslinjer-for-forskning-pa-internett.pdf

Pothier, D.D. (2008). Written consent: sometimes more trouble than it is worth? Research Ethics, 4: 78-79. http://dx.doi.org/10.1177/174701610800400212

Renzetti, C.M. and Lee, R.M. (1993). Overview and introduction. In: Renzetti, C.M. and Lee, R.M. (eds.) Researching sensitive topics. London: Sage.

Rettie, R. (2009). Mobile phone communication: extending Goffman to mediated interaction. Sociology, 43(3): 421-438. http://dx.doi.org/10.1177 /0038038509103197

Rodham, K. and Gavin, J. (2006). The ethics of using the Internet to collect qualitative research data. Research Ethics Review, 2: 92-97. http://dx.doi.org /10.1177/174701610600200303

Smith, D.S. (2007). Texts and the ontology of organizations and institutions. Studies in Cultures, Organizations and Societies, 7: 159-198. http://dx.doi.org/10.1080 /10245280108523557

Szmigin, I. and Reppel, A.E. (2004). Internet community bonding: the case of macnews.de. European Journal of Marketing, 38: 626-640. http://dx.doi.org /10.1108/03090560410529259

Tjora, A. (2011). Invisible whispers: accounts of SMS communication in shared physical space. Convergence: The International Journal of Research into New Media Technologies, 17(2): 193-211. http://dx.doi.org/10.1177 /1354856510394604

Tjora, A., Henriksen, I. M., Fjærli, T. og Grønning, I. (2012). Sammen i byen. En sosiologisk analyse av urbane naboskap, nærmiljø og boligens betydning. Oslo: Tapir Akademisk forlag 